\title{
クレンチアゼムの蛋白結合に関する研究
}

\author{
福島 健, 仲村進, 伊藤 豊*, 高市 雄之 \\ 田辺製薬株式会社 薬物代謝研究所，薬理研究所* †335 埼玉県戸田市川岸2-2-50
}

Key words : Clentiazem, Protein binding, Human plasma protein, Human serum albumin, $\alpha_{1}$-Acid glycoprotein

\section{Studies on the protein binding of clentiazem}

Takeshi Fukushima, Susumu Nakamura, Yutaka Ito*, and Osasi Takaiti Research Laboratory of Drug Metabolism, Pharmacological Research Laboratory*, Tanabe Seiyaku Co., Ltd., 2-2-50, Kawagishi, Toda, Saitama, 335, Japan

\section{Summary}

The binding of clentiazem to human plasma protein and to three purified proteins were measured in vitro. The effect of interaction with various other drugs, which might be used for combined therapy, on the binding of clentiazem was also measured. The percentage of clentiazem bound to human plasma protein was found to be constant (ca. 90\%) at the concentration range of $20 \sim 10,000 \mathrm{ng} / \mathrm{ml}$. It would be thought that clentiazem was mainly bound to the albumin fraction of plasma and the binding characteristics of clentiazem to albumin was non-specific. No interference of the various other drugs on the binding of clentiazem to plasma protein were found. 


\section{序}

クレンチアゼム $((+)(2 \mathrm{~S}, 3 \mathrm{~S})-3-$ acetoxy-8chloro $-5-(2-($ dimethylamino $)$ ethyl $)-2,3-\mathrm{di}$ hydro-2-(4- methoxyphenyl) -1, 5- benzothiazepin-4-(5H)-one maleate, TA-3090) は, ジルチアゼムの 8 位に塩素原子を導入したジルチ アゼムの誘導体であり，田辺製薬侏にて開発中の 新規 $\mathrm{Ca}$ 拮抗薬である. 本薬物は摘出血管 $\mathrm{Ca}$ 収縮に対する緩解作用，また高血圧モデル動物に おいて、ジルチアゼムよりも持続的な降圧作用, ならびに冠血流量および椎骨動脈血流量増加作用 が認められている1 3). 今回, クレンチアゼムの 体内動態研究の一環として, ヒト血漿蛋白纱よび 各種精製蛋白への結合率, アルブミンならびに $\alpha_{1}$ 一酸性糖蛋白への結合様式, さらにクレンチアゼ ムの蛋白結合に及ぼす臨床上の予想併用薬の影響 について検討した。

\section{実験材料および実験方法}

\section{1. 化合物および試薬}

${ }^{14} \mathrm{C}$-クレンチアゼムはアマシャムインターナ ショナル (Buckinghamshire, U.K.) にて合 成された（Lot No. CFQ5242）。比放射能は1.84 $\mathrm{MBq} / \mathrm{mg}$, 放射化学的純度は薄層クロマトグラ フィーで検討した結果 $98 \%$ であった。標識体は必 要に応じ非標識体で希釈して実験に供した。予想 併用薬のジクマロールは Aldrich より, フロセ ミドは東京化成から，またジゴキシン，アスピリ ンはナカライテスクより購入した。デノパミン, アテノロール, カプトプリル, イデベノンは当社 有機化学研究所で合成された. グリペンクラミド はオイグルコン錠 (山之内製薬)，チクロピジン はパナルジン錠（第一製薬）より抽出したものを
用いた．精製蛋白のヒト血清アルブミン（HSA）, ウシ血清アルブミン（BSA）およびヒト $\alpha_{1}$-酸性 糖蛋白（ $\left.\alpha_{1}-\mathrm{AGP}\right)$ は Sigma 社より購入した.

\section{2. ヒト血漿}

健常成人男子志願者 6 名 (平均年齢 41 歳, 平均 体重 $65 \mathrm{~kg}$ ）から採取した血液を，遠心分離（4 ${ }^{\circ} \mathrm{C}, 3,500 \mathrm{rpm}$, 10 分）することにより血漿を得 た。

\section{3. 限外濾過膜への吸着}

ヒト血漿を限外濾過膜（セントリーフリー, MPS-3，アミュン）で濾過して得られた濾液に, 4 種の濃度の ${ }^{14} \mathrm{C}-$ クレンチアゼム溶液 $10 \mu l$ (最終 濃度 : $20,100,1,000,10,000 \mathrm{ng} / \mathrm{m} l)$ を加光, $37^{\circ} \mathrm{C} て ゙ 10$ 分間インキュベート後, 限外濾過を行っ た. 濾過前後での放射能を測定することにより， 各濃度での限外濾過膜に対する吸着率を算出した。

\section{4. 血墏蛋白への結合}

${ }^{14} \mathrm{C}$-クレンチアゼムのヒト血漿蛋白への結合率 を限外濾過膜を用いて測定した。 ヒト血漿 $1 \mathrm{ml}$ を試験管に採り， $37^{\circ} \mathrm{C} て ゙ 5$ 分間プレインキュベー トした後, ${ }^{14} \mathrm{C}$-クレンチアゼム水溶液の $10 \sim 20 \mu l$ を加えた。 ${ }^{14} \mathrm{C}$ ークレンチアゼムの濃度はヒト血漿 中の最終濃度が20, 50, 100, 300, 1, 000, 3, 000 および $10,000 \mathrm{ng} / \mathrm{m} l$ となるように調製した。 37 ${ }^{\circ} \mathrm{C}$ で 5 分間インキュベートし，その $100 \mu l$ にシン チレーター（クリアゾル，ナカライテスク）を加 え放射能を測定した，次いで，残りをセントリー フリーに注入し， $37^{\circ} \mathrm{C} に て 5$ 分間， $3,000 \mathrm{rpm}$ で遠心することにより限外濾過し，その濾液の $100 \mu l$ の放射能を前記同様にして測定した，血漿 蛋白結合率は Graben，R.D.4) らが用いた次式 により求めた。

$$
\text { 結合率 }(\%)=\frac{(\text { 濾過前の溶液の放射能－濾過の放射能 }) \times(100-\text { 吸着率 }(\%))}{\text { 濾過前の溶液の放射能 }} \times 100
$$

なお, 今回用いた標識体の比放射能 $(1.84 \mathrm{MBq} /$ $\mathrm{mg})$ から定量限界は $100 \mathrm{ng} / \mathrm{m} l$ と計算された. そのため, クレンチアゼム濃度が $50 \mathrm{ng} / \mathrm{m} l$ 以下 での結合率は, 血漿を数本のセントリーフリーに 分けて限外濾過を行い, 各濾液の一定量を合して 放射能を測定することにより求めた.

\section{6. 血漿蛋白結合の可逆性}

ヒト血漿 $1 \mathrm{~m} l$ に ${ }^{14} \mathrm{C}-$ クンチアゼムの試験溶 液を加光（血漿中の ${ }^{14} \mathrm{C}-$ クレンチアゼム濃度は $0.1 \mu \mathrm{g} / \mathrm{m} l), 37^{\circ} \mathrm{C}$ で10分間インキュベート後, $0.1 \mathrm{~m} l$ を放射能の測定用に分取し, 次いで残り の血漿にメタノール $3 \mathrm{~m} l$ を加えて振盪, 遠心分 
離（3,000rpm， $4{ }^{\circ} \mathrm{C} ， 10$ 分） して上清を分取し た. 残渣にメタノール $3 \mathrm{~m} l$ を加穴, 前記同様の 操作を行い上清を分取した。 上清を合わし，その 一部の放射能を測定した。ささらに, 残渣に $1 \mathrm{~N}$ $\mathrm{NaOH} 2 \mathrm{~m} l$ を加光溶解後, $3 \mathrm{M}$ TCA $1 \mathrm{~m} l$ を加えて，再度蛋白を凝固させた． $80 \%$ メタノー ル $3 \mathrm{ml}$ を加光振盪後, 遠心分離して上清を分取 した.この操作をさらに 2 回行い, 各上清の一部 の放射能を測定した．残渣は蛋白溶解剂（Solue ne 350, Packard) $1 \mathrm{~m} l$ を加光, 加温溶解後, 放射能を測定した。

\section{6. 精製蛋白への結合}

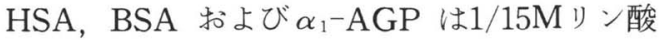
緩衝液 (pH7.4) に溶解し, 結合実験時の最終濃 度がそれぞれ $40 \mathrm{mg} / \mathrm{m} l, 40 \mathrm{mg} / \mathrm{m} l$ および 1 $\mathrm{mg} / \mathrm{m} l$ になるよらに調製した。これらの濃度は 健常人あるいは健康なイ又の血漿中濃度に相当す

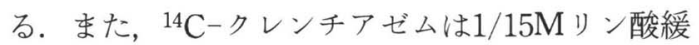
衝液 (pH7.4) 飞溶解し, 実験時の最終濃度が $0.01 \mu \mathrm{g} / \mathrm{m} l, \quad 0.03 \mu \mathrm{g} / \mathrm{m} l$ および $0.3 \mu \mathrm{g} / \mathrm{m} l$ にな るように調製した。

蛋白溶液の一定量を $37^{\circ} \mathrm{C} て ゙ 5$ 分間プレインキュ ベート後, 所定の濃度に調製した ${ }^{14} \mathrm{C}-$ クレンチア ゼム溶液の一定量を加えた。 5 分間インキュベー トした後, その一部の放射能を測定し, 残りの溶 液は前記同様に処理して蛋白結合率を求めた。な 扣, 限外濾過膜への吸着補正は前記同様にして 行った.

\section{7. 結合様式}

${ }^{14} \mathrm{C}$-クレンチアゼムの最終濃度が $0.05 \sim 400$ $\mu \mathrm{g} / \mathrm{m} l$ の範囲で, HSA に対する結合率を限外 濾過法により求めた。 また, ${ }^{14} \mathrm{C}$ ークレンチアゼム の0. 05 $100 \mu \mathrm{g} / \mathrm{m} l$ の濃度範囲における $\alpha_{1}-\mathrm{AGP}$ に対する結合率を前記と同様にして求めた。

クレンチアゼムの各濃度に打ける結合率より, クレンチアゼムの結合型濃度 $(\mathrm{Cb})$ 扎よび非結 合型濃度 (Cf) を算出し, Langmuir プロット （1式）および Scatchard プロット（2式）に より結合様式を解析した。なお，HSA 拈よび $\alpha_{1}$ -AGP の分子量はそれぞれ 66,500 抢よび44, 100 とした5).
(1) $\mathrm{r}=\mathrm{n} \cdot \mathrm{K} \cdot \mathrm{Cf} /(1+\mathrm{K} \cdot \mathrm{Cf})$

(2) $\mathrm{r} / \mathrm{Cf}=\mathrm{n} \cdot \mathrm{K}-\mathrm{K} \cdot \mathrm{r}$

$\mathrm{r}$ : 蛋白 1 分子に結合したクレンチアゼムの 分子数

$\mathrm{n}$ : 蛋白分子の結合サイト数, $\mathrm{K}$ ：会合定数

\section{8. 薬物相互作用}

クレンチアゼムとの相互作用を検討するため被 検薬としてジゴキシン（最終濃度 : $5 \mathrm{ng} / \mathrm{m} l$ ), ジクマロール (最終濃度 : $150 \mathrm{ng} / \mathrm{ml})$, グリベ ソクラミド (最終濃度 : $150 \mathrm{ng} / \mathrm{m} l$ ), フロセミ ド (最終濃度 : $5 \mathrm{ng} / \mathrm{m} l$ ), チクロピジン（最終 濃度 : $1 \mu \mathrm{g} / \mathrm{m} l$ ), カプトプリル（最終濃度 : $1.5 \mu$ $\mathrm{g} / \mathrm{m} l)$, アテノロール (最終濃度 : $700 \mathrm{ng} / \mathrm{m} l$ ), デノパミン（最終濃度 : $100 \mathrm{ng} / \mathrm{m} l$ ), イデベノ ン（最終濃度： $1 \mu \mathrm{g} / \mathrm{m} l$ ) を用いた。被検薬は血 漿 $1 \mathrm{~m} l$ に対して $10 \sim 20 \mu l$ を添加し, 上記の濃 度となるように調製した。 $37^{\circ} \mathrm{C} に て 5$ 分間プレイ

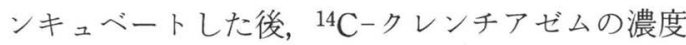
が100ng/ml になるよらに加えた. クレンチア ゼム添加後の処理は上記之同様に行い, クレンチ アゼムの結合率を求めた。

\section{結 果}

\section{1. 限外濾過膜への吸着}

限外濾過膜への吸着率は Table I に示したよ らに, クレンチアゼム濃度の上昇に伴い減少した. これらの濃度と吸着率との関係を最小二乗法によ り求めた結果, 次式の関係が得られた. したがっ て，クレンチアゼムの任意の濃度における限外濾 過膜への吸着率は，この式によって算出でさると 考劣られた。

吸着率 $(\%)=49.635-8.0893 \times \log ($ クレン チアゼム濃度 $(\mathrm{ng} / \mathrm{m} l)$ ) $\mathrm{r}=0.93$

Table I Adsorption to ultrafiltration membrane

\begin{tabular}{cc}
\hline \hline $\begin{array}{c}\text { clentiazem conc. } \\
(\mu \mathrm{g} / \mathrm{m} l)\end{array}$ & $\begin{array}{c}\text { adsorption } \\
(\%)\end{array}$ \\
\hline 0.02 & 39.1 \\
0.1 & 32.3 \\
1 & 27.7 \\
10 & 16.2 \\
\hline
\end{tabular}

Each value represents the mean value for $2 \mathrm{ex}$ periments. 
Table II Binding of ${ }^{14} \mathrm{C}$-clentiazem to human plasma protein

\begin{tabular}{cc}
\hline \hline $\begin{array}{c}\text { clentiazem conc. } \\
(\mu \mathrm{g} / \mathrm{m} l)\end{array}$ & $\begin{array}{c}\text { Bound fraction } \\
(\%)\end{array}$ \\
\hline 0.02 & $87.9 \pm 1.3$ \\
0.05 & $90.8 \pm 0.9$ \\
0.1 & $90.2 \pm 0.7$ \\
0.3 & $90.5 \pm 1.1$ \\
1 & $90.9 \pm 1.2$ \\
3 & $90.8 \pm 0.5$ \\
10 & $90.4 \pm 0.8$ \\
\hline
\end{tabular}

Each value represents the mean \pm S.D. for 6 experiments.

以下に示す蛋白結合率は，この式を用いて吸着 率を求め補正した。

\section{2. ヒト血漿蛋白への結合}

ヒト血漿蛋白に対する結合率を Table II に示 した、 ${ }^{14} \mathrm{C}$ ークレンチアゼムのヒト血漿蛋白に対す る結合率は, クレンチアゼムの濃度が $20 \mathrm{ng} / \mathrm{ml}$ のときに若干低い值を示したが, $10,000 \mathrm{ng} / \mathrm{m} l$ までのいずれの濃度に拈いても約 $90 \%$ と一定で あった。

\section{3. 血漿蛋白結合の可逆性}

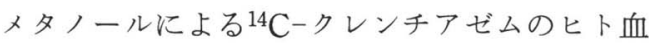
漿からの抽出率を Table III 示した. メタノー ルへの放射能の抽出率は添加放射能の $98.4 \%$ に達 し, さらに $1 \mathrm{~N} \mathrm{NaOH}$ および3M TCA 処理後 にメタノール抽出された放射能を含めると $99.2 \%$ が抽出され，残渣中の放射能は $0.5 \%$ にすぎな かった。

\section{4. 精製蛋白への結合}

クレンチアゼムの各種精製蛋白に対する結合率 を Table Nに示した. クレンチアゼムの 3 種の 濃度 $(0.01,0.03,0.3 \mu \mathrm{g} / \mathrm{m} l)$ に打壮る HSA に対する結合率は，それぞれ49.5\%，55.8\%拈よ び51. $2 \%$ であり，クレンチアゼム濃度のいずれに おいても活洼同じであった。 また，BSA に対す る結合率は55.7\%，53.3\%执よび57.8\%と HSA に対する結合率より若干高かったが，HSA の場 合と同様，各濃度間で差は認められなかった。 た， $\alpha_{1}-\mathrm{AGP}$ に対するクレンチアゼムの結合率 は15.5〜20.3\%であった.

Table III Reversibility of binding of ${ }^{14} \mathrm{C}$-clentiazem to human plasma protein by methanol extraction method

\begin{tabular}{ccccc}
\hline \hline Sample No. & $\begin{array}{c}\mathrm{MeOH} \text { ext. } \\
(\%) *\end{array}$ & $\begin{array}{c}\mathrm{MeOH} \text { ext. } \\
(\%) * *\end{array}$ & $\begin{array}{c}\text { Total ext. } \\
(\%)\end{array}$ & $\begin{array}{c}\text { Residue } \\
(\%)\end{array}$ \\
\hline 1 & 98.2 & 0.9 & 99.1 & 0.6 \\
2 & 98.6 & 0.7 & 99.3 & 0.5 \\
3 & 98.3 & 0.8 & 99.1 & 0.5 \\
\hline mean \pm S.D. & $98.4 \pm 0.2$ & $0.8 \pm 0.1$ & $99.2 \pm 0.1$ & $0.5 \pm 0.0$ \\
\hline
\end{tabular}

* : The percentage of $80 \% \mathrm{MeOH}$ extracts

**: The percentage of $80 \% \mathrm{MeOH}$ extracts after treatment with $0.1 \mathrm{~N}$ $\mathrm{NaOH}$ and $3 \mathrm{M}$ TCA

Table $\mathrm{N}$ Protein binding of ${ }^{14} \mathrm{C}$-clentiazem to purified proteins $(\%)$

\begin{tabular}{ccccc}
\hline \hline \multirow{2}{*}{ protein } & conc. & \multicolumn{3}{c}{ Bound fraction (\%) } \\
\cline { 3 - 5 } & & $0.01^{*}$ & $0.03^{*}$ & $0.3^{*}$ \\
\hline HSA & 40 & $49.5 \pm 3.2$ & $55.8 \pm 3.1$ & $51.2 \pm 1.4$ \\
BSA & 40 & $55.7 \pm 0.9$ & $53.3 \pm 3.9$ & $57.8 \pm 1.9$ \\
$\alpha_{1}$-AGP & 1 & $19.0 \pm 3.6$ & $15.5 \pm 5.3$ & $20.3 \pm 6.2$ \\
\hline *Concentration of clentiazem $(\mu \mathrm{g} / \mathrm{m} l)$ & \multicolumn{3}{r}{ (mean \pm S.D. $\mathrm{n}=3)$}
\end{tabular}


HSA

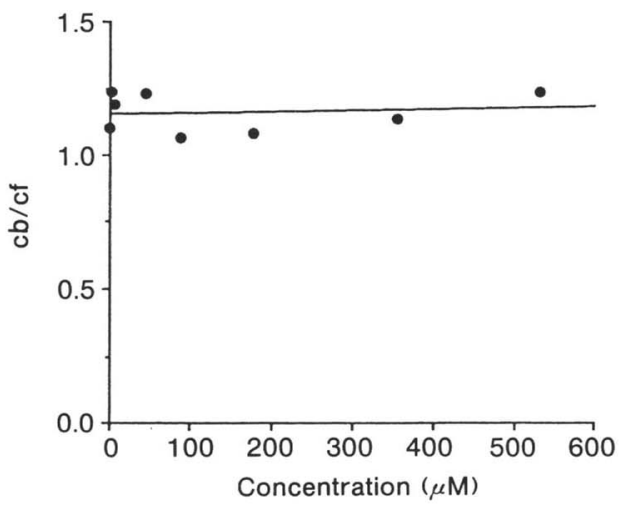

$\alpha$ l-AGP

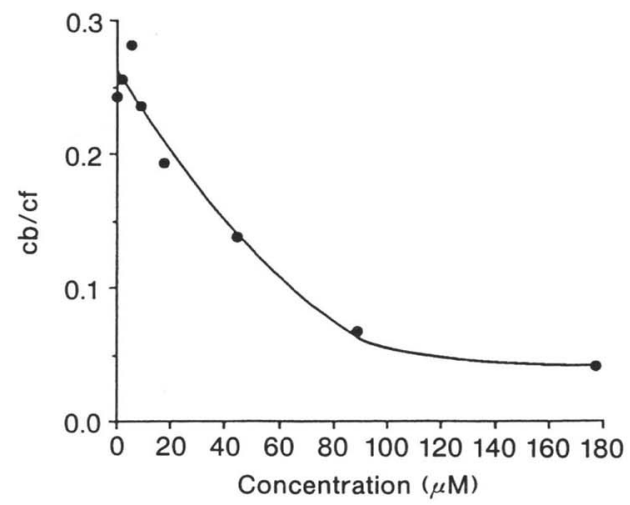

Fig. 1 The relationship between clentiazem concentration $(\mu \mathrm{M})$ and the ratio of the concentration of free drug $(\mathrm{Cf})$ to bound drug $(\mathrm{Cb})$
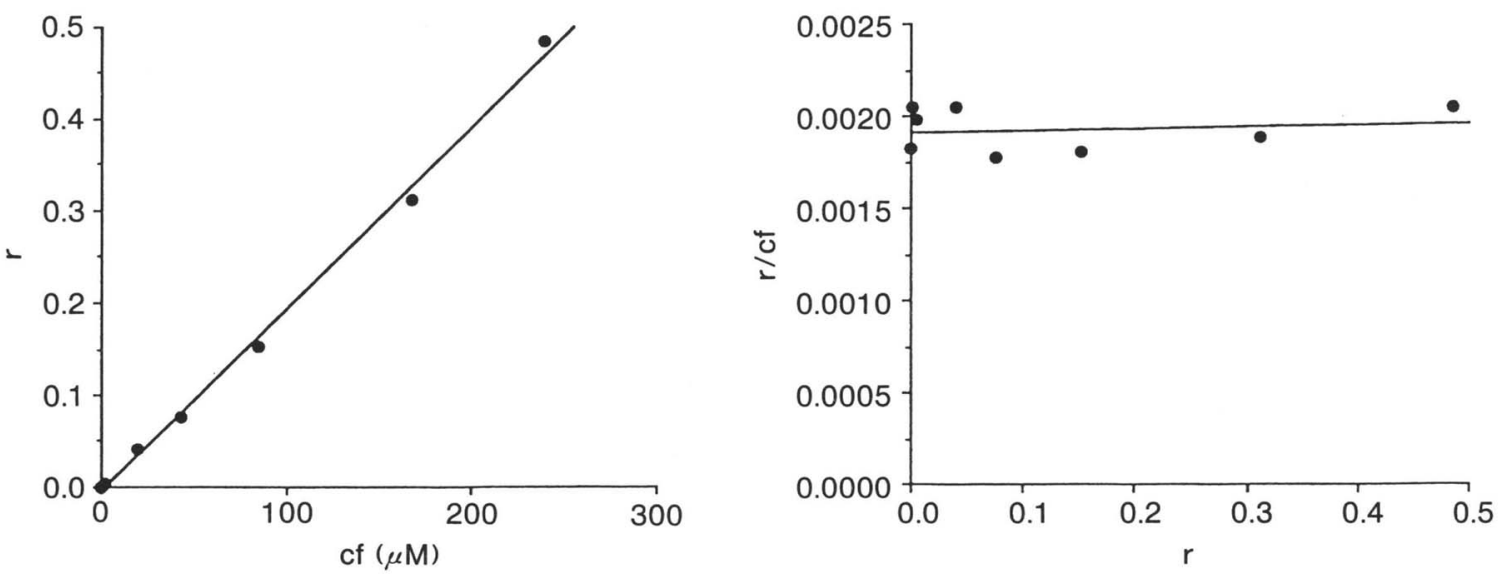

Fig. 2 Plots of clentiazem and HSA interaction $r$ : The moles of bound drug per a mole of protein $\mathrm{Cf}$ : The concentration of free drug $(\mu \mathrm{M})$

\section{5. 結合様式}

クレンチアゼムの濃度を変化させたときのクレ ンチアゼムと HSA，あるいは $\alpha_{1}-\mathrm{AGP}$ との結 合に扮ける結合型薬物濃度 $(\mathrm{Cb})$ と非結合型薬 物濃度（Cf）の比 $(\mathrm{Cb} / \mathrm{Cf})$ の関係を Fig. 1 に 示した。

HSA に和いて $\mathrm{Cb} / \mathrm{Cf}$ 值は, クレンチアゼム の濃度の上昇にかかわらず，ほぼ一定であった. 一方, $\alpha_{1}-\mathrm{AGP}$ に扎いては, クレンチアゼムの 濃度の増加に伴い，二相性の低下を示した。 これ
らの結果から, クレンチアゼムの HSA への結 合は非特異的であり， $\alpha_{1}-\mathrm{AGP}$ に対しては特異 的に結合することが示唆される.

これらのことを確認するため, Langmuir お。 よび Scatchard プロットによる解析を行った.

Fig. 2 にクレンチアゼムの HSA への結合の関 係を, Langmuir プロットおよび Scatchard プ ロットで表した. Langmuir プロットでは, ク レンチアゼムの非結合型薬物濃度 (Cf) と HSA に結合する分子数（r) の間に線形性が認められ 

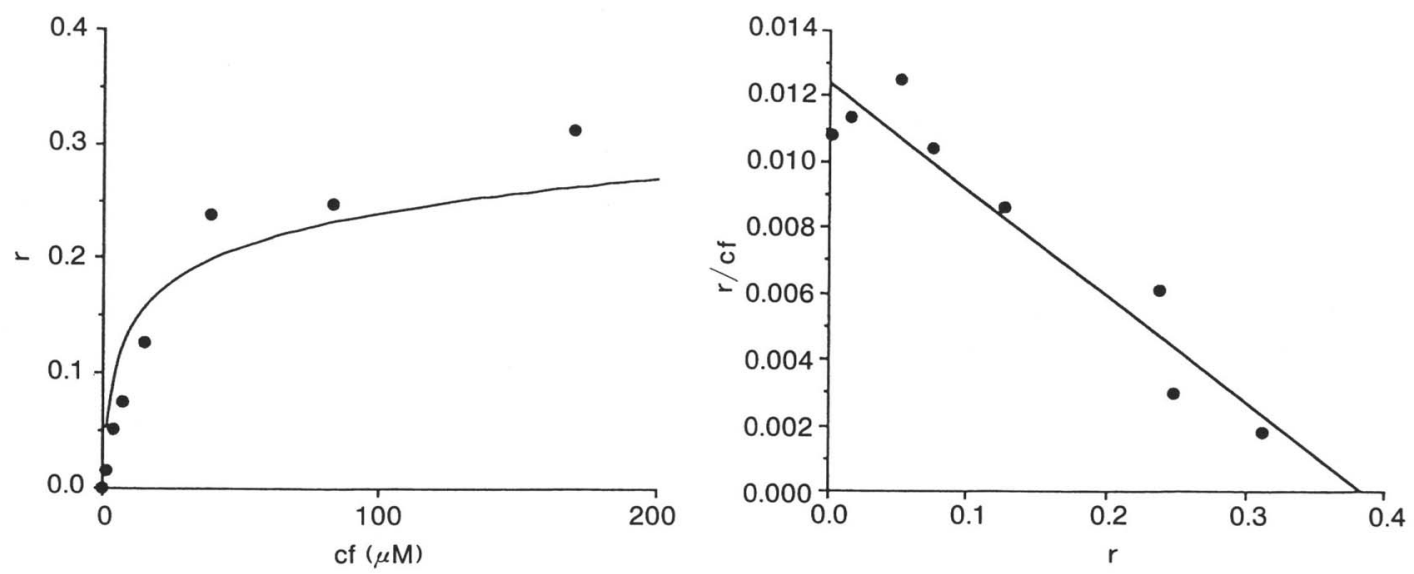

Fig. 3 Plots of clentiazem and $\alpha_{1}-$ AGP interaction $r$ : The moles of bound drug per a mole of protein Cf : The concentration of free drug $(\mu \mathrm{M})$

Table $\mathrm{V}$ Effect of other drugs on the binding of ${ }^{14} \mathrm{C}$-clentiazem $(100 \mathrm{ng} / \mathrm{m} l)$ to human plasma protein

\begin{tabular}{lcc}
\hline & drugs & Bound fraction $(\%)$ \\
\hline & control & $90.2 \pm 0.7$ \\
\hline Ticlopidine & $(1 \mu \mathrm{g} / \mathrm{m} l)$ & $91.1 \pm 0.8$ \\
Dicumarol & $(150 \mathrm{ng} / \mathrm{m} l)$ & $90.8 \pm 1.0$ \\
Glibenclamide & $(150 \mathrm{ng} / \mathrm{m} l)$ & $91.9 \pm 1.0$ \\
aspirin & $(300 \mu \mathrm{g} / \mathrm{m} l)$ & $89.6 \pm 1.0$ \\
\hline & control & $92.6 \pm 0.3$ \\
\hline Idebenon & $(1 \mu \mathrm{g} / \mathrm{m} l)$ & $92.1 \pm 0.4$ \\
Atenolol & $(700 \mathrm{ng} / \mathrm{m} l)$ & $92.8 \pm 0.5$ \\
Furosemide & $(5 \quad \mathrm{ng} / \mathrm{m} l)$ & $92.5 \pm 0.8$ \\
Digoxin & $(5 \quad \mathrm{ng} / \mathrm{m} l)$ & $91.8 \pm 0.5$ \\
Denopamine & $(100 \mathrm{ng} / \mathrm{m} l)$ & $92.1 \pm 0.8$ \\
Captopril & $(1.5 \mu \mathrm{g} / \mathrm{m} l)$ & $92.2 \pm 0.4$ \\
\hline
\end{tabular}

Since experiments were divided into two groups, each control value was in each experiment.

Each value represents the mean \pm S.D. of 6 experiments.

た、また，Scatchard プロットに纱いては，r の増加に対して, r/Cf は注ぼ一定であった。 こ のよらな挙動を示寸薬物の結合は非特異的な結合 と考光られ6), クレンチアゼムの HSA に対する 結合も非特異的であると考えられた.

Fig. 3 にクレンチアゼムの $\alpha_{1}-\mathrm{AGP}$ に対する 結合を, Langmuir プロットおよび Scatchard
プロットで示した. クレンチアゼムの非結合型薬 物濃度 (Cf) に対寸る $\mathrm{r}$ 值は低濃度域（1～10 $\mu \mathrm{g}$ ) $\mathrm{m} l$ ) では線形性を示し, 高濃度域では非線形性 を示した。 また， r 值の増加に伴い，r/Cf 值が 直線的に低下寸ることから，クレンチアゼムが $\alpha_{1}$ -AGP の特異的な結合サイトに結合することが 示唆された．結合サイト数（n）は約 0.4 であり, 
会合定数（k） は直線の傾きから求めた結果 3.43 $\times 10^{4} \mathrm{M}^{-1}$ であった. 以上の結果から, クレンチ アゼムのアルブミンへの結合様式は非特異的であ り， $\alpha_{1}-\mathrm{AGP}$ に対しては特異的であると考光ら れる。

\section{6. 薬物相互作用}

クレンチアゼムのヒト血漿蛋白との結合に対し, 併用が予想される各種薬物による影響を検討し, その結果を Table V に示した。実験に用いたク レンチアゼムの濃度は, ${ }^{14} \mathrm{C}-$ クレンチアゼムの比 放射能に基づく限外濾過法による結合率測定の定 量限界である $100 \mathrm{ng} / \mathrm{m} l$ とした。一方，ヒトに 打けるクレンチアゼム $50 \mathrm{mg}$ 経口投与時の $\mathrm{C}_{\text {max }}$ は約 $30 \mathrm{ng} / \mathrm{m} l$ であった7). そのため, 被検薬の 濃度もそれぞれの示す $\mathrm{C}_{\max }$ の約 3 倍となるよう に設定した。各種併用薬共存下でのクレンチアゼ ムのヒト血漿蛋白結合率は対照值と同程度であり， 検討した併用薬はクレンチアゼムの蛋白結合率に 対して影響を及ぼさなかった。

\section{考 察}

一般的に塩基性薬物は $\alpha_{1}-\mathrm{AGP}$ に対する結合 率が高く, 酸性薬物ではアルブミンへの結合率が 高いことが知られている8). しかしながら，塩基 性薬物である ${ }^{14} \mathrm{C}$ ークレンチアゼムの HSA およ び BSA への結合率 (約50\%) は $\alpha_{1}-\mathrm{AGP} へ の$ 結合率（約15２0\%）よりも高かった. したがっ て, クレンチアゼムの血漿中に抢ける主要結合蛋 白種はアルブミンであると判断され，さらに $\alpha_{1}-$ AGP への結合も血漿蛋白結合率に寄与すると考
えられる。 また, HSA や $\alpha_{1}-\mathrm{AGP}$ 以外にも,

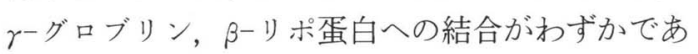
るが認められている(未発表データ). クレンチ アゼムの血漿蛋白結合は, 血漿に添加したほとん どの放射能がメタノールにより抽出されたことか ら，可逆的な結合であると考えられる.

クレンチアゼムのヒト血漿蛋白への結合率は, $20 \sim 10,000 \mathrm{ng} / \mathrm{m} l$ の濃度範囲で約 $90 \%$ とほぼ一 定であった. 主要結合蛋白種であるアルブミンヘ のクレンチアゼムの結合様式は, Langmuir お よび Scatchard ブロットによる解析から, 特異 的な結合サイトを持たない非特異的結合であると 考学られた，薬物が血漿蛋白に対し特異的な結合 サイトをもつ場合, 薬物の濃度上昇に伴い, 蛋白 結合率の減少が観察される。しかしながら, クレ ンチアゼムの主要結合蛋白種がアルブミンであり, その結合様式が非特異的であるために, クレンチ アゼムの濃度上昇に伴らヒ卜血漿蛋白結合率の減 少が認められなかったと考光られる.

クレンチアゼムの血漿蛋白結合に対して臨床上 で併用が予想される薬物は影響しなかった。 クレ ンチアゼムは上述したよらに主にアルブミンと結 合し，その結合様式が非特異的であることから， 予想併用薬によって影響されなかったものと考光 られる。

本研究により, 病態時で変動しやすい $\alpha_{1}-\mathrm{AGP}$ よりもアルブミンへ主に結合すること, また, 臨 床上併用の可能性がある他の薬物によってその結 合が影響されないこと, などクレンチアゼムの血 漿蛋白結合の特徵が明らかにされた。

\section{文 献}

1) Narita, H., Murata, S., Yabana, H., Kikkawa, K., Sugawara, Y., Akimoto, Y. and Nagao, T. : Long-lasting hypotensive and antihypertensive effects of a new 1,5-benzothiazepine calcium antagonist in hypertensive rats and renal hypertensive dogs. Arzneim.-Forsch./Drug Res. 38:4, 515 -520 (1988).

2) Murata, S., Kikkawa, K., Yabana, H. and Nagao, T. : Cardiovascular effects of a new 1,5-benzothiazepine calcium antagonist in anesthetized dogs. Arzneim.-Forsch./Drug Res. $38: 4$, 521-525 (1988).

3) Kikkawa, K., Murata, S. and Nagao, T. : Calcium antagonistic and spasmolytic activities of a new 1,5-benzothiazepine derivative in isolated canine and monkey arteries. Arzneim.-Forsch./Drug Res. $38: 4$, 526-531 (1988).

4) Graben, R.D. and Parsons, D.L. : Effects of a perfluorochemical blood 
substitute on diazepam binding by human albumin. J. Pharm. pharmacol., $40: 684-688$ (1988).

5) Maruyama, T., Otagiri, M., and Schulman, S.G. : Binding characteristics of coumarin anticoagulants to human $\alpha_{1}$-acid glycoprotein and human serum albumin. Int. J. Pharm., 59 : 137-143 (1990).

6) 小田切優樹, 杉山雄一：薬物のタンパク結合実験法, 廣川書店, pp. 23-26 (1991).

7）弘田雄三, 河村慧四郎, 林佐栄子, 森岡淳夫, 寺崎由香, 北山博一, 野田和夫 : TA -3090の臨床第一相試験（第一報）一経口単回投与試験一, 臨床医薬, 7 : 1891-1908 (1991).

8）小田切優樹, 杉山雄一：薬物のタンパク結合実験法, 廣川書店, pp. 1-22 (1991). 